\title{
From classical developmentalism and post-Keynesian macroeconomics to new developmentalism
}

\author{
Do desenvolvimentismo clássico e da macroeconomia \\ pós-Keynesiana ao novo desenvolvimentismo
}

LUIZ CARLOS BRESSER-PEREIRA*;**

\begin{abstract}
RESUMO: O novo desenvolvimentismo foi uma resposta à incapacidade do desenvolvimentismo clássico e da macroeconomia pós-keynesiana em liderar os países de renda média para retomar o crescimento. O novo desenvolvimentismo nasceu nos anos 2000 para explicar por que os países latino-americanos pararam de crescer nos anos 1980, enquanto os países do Leste Asiático continuaram a se recuperar. Este artigo compara o novo desenvolvimentismo com o desenvolvimentismo clássico, que não tinha uma macroeconomia, e com a economia pós-keynesiana, cuja macroeconomia não é dedicada aos países em desenvolvimento. E mostra que seguir o exemplo do Leste Asiático não é suficiente política industrial, é também necessária uma política macroeconômica que defina os cinco preços macroeconômicos direito, rejeita o crescimento com a política de poupança externa e mantém as contas macroeconômicas equilibradas.

PALAVRAS-CHAVE: Desenvolvimentismo clássico; macroeconomia pós-keynesiana; países do Leste Asiático; Países da América Latina.
\end{abstract}

ABSTRACT: New developmentalism was a response to the inability of classical developmentalism and post-Keynesian macroeconomics in leading middle-income countries to resume growth. New developmentalism was born in the 2000s to explain why Latin American countries stopped growing in the 1980s, while East Asian countries continued to catch up. This paper compares new developmentalism with classical developmentalism, which didn't have a macroeconomics, and with post-Keynesian economics, whose macroeconomics is not devoted to developing countries. And shows that to follow the East Asian example is not enough industrial policy, it is also necessary a macroeconomic policy that sets the five macroeconomic prices right, rejects the growth with foreign savings policy, and keeps the macroeconomic accounts balanced.

KEYWORDS: Classical developmentalism; post-Keynesian macroeconomics; East Asian countries; Latin American countries.

JEL Classification: O10; O11; B29.

\footnotetext{
* Emeritus professor of Fundação Getulio Vargas, São Paulo/SP, Brasil. E-mail: bresserpereira@gmail. com. Submitted: 14/July/2018; Approved: 10/September/2018.

** I express my thanks to Pierre Salama for his comments.
} 
Historical schools of economics are always a reflection of their time and a critique of competing theories. They build theories or models that explain how the real economic systems work and offer policies to confront obstacles and achieve economic objectives - essentially, to achieve growth with stability and reduction of economic inequality. The classical political economy school, for instance, reflected the growth experience of the first industrialized countries (England, Belgium and France), the formation of their nation-states and their industrial revolutions, and it criticized mercantilism. Marxian political economy was an analysis of capitalism, and a critique of the former classical economists; Keynesian macroeconomics was a response to the 1930s Great Depression, and a critique of neoclassical supply sided economics. These schools of thought search to generalize out of the observed historical regularities and tendencies and permanently check whether or not they correspond to reality, while the neoclassical and the Austrian schools adopt the hypothetic-deductive method, and, although they deny it, are not really concerned the theory has a counterpart in the historical reality, because their criterion of truth is not the adequacy to reality, but the criterion proper of the methodological science: the internal logical consistency. ${ }^{1}$ In this first paper, I will discuss only the three modern historical schools of economic development, which also reflect their time. Classical developmentalism reflected the conditions and challenges confronted by underdeveloped countries after the Second World War; new institutionalism is an attempt to provide the neoclassical school with a historical explanation of growth; and new developmentalism is a theory based on the successful experiences of growth of middle-income countries, particularly of Brazil's and the East Asian countries.

Economic theory is necessarily ingrained in the historical experience of capitalist development. In the eighteenth century, humanity invented progress. With the Enlightenment, the constitutional revolutions in England, United States and France, and the Industrial Revolution in England, history ceased to be viewed as a succession of civilizations or of empires that rose, came to hegemony, and experienced decadence, to be a process of long-term advancement of knowledge, reason, and material well-being. In the nineteenth century, while the development of science confirmed the hopes in the progress of reason, socialism and Marx's theory of history opened room for the possibility of a just society. In the first part of the twentieth century, two bloody world wars and the rise of fascism in Italy and Germany put an end to this optimistic view of history. Yet, it was reborn after World War II with the idea of economic development. While progress was the utopia of philosophers, and socialism, the utopia of revolutionary intellectuals, economic development was the project of economists - not of neoclassical economists, who dominate

\footnotetext{
${ }^{1}$ Neoclassical economists naturally deny this fact while engaged in econometric testing, but the fact is that when the researches and the intrinsic instability of the capitalist system falsify their models, they claim that rejecting a logically coherent theory would be a "naive falsificationism" (Popper, 1934) and stay with it.
} 
the profession since the end of nineteenth century (with a Keynesian interruption between the 1940s and the 1970s), but of heterodox economists (Marxian, Schumpeterian, historical institutionalists and Keynesian), who developed a school of thought fully devoted to economic development, "development economics", while criticizing neoclassical economics. In Latin America, development economics came to be called "structuralism". Given the excessive generality of these two names, I will adopt, instead, the expression "classical developmentalism". In the 1990s, some neoclassical economists, unhappy with a historical explanation for growth, created its own historical theory, "new institutionalism". Finally, in the mid 2000s, "new developmentalism" started to be formulated.

Economics or, considering its original name, political economy, is the science of real economic systems coordinated by the market and the state; is the science of prices; it is a historical science that studies the growth, distribution of income and wealth, and the stability or instability of national economic systems and their relationship with the world economic system. Yet, this definition ceased to be consensual when, in the end of the nineteenth century, the neoclassical school turned dominant and became an abstract, hypothetical-deductive, body of knowledge with no real commitment with reality. In this event, the name of the science was changed from political economy to economics. If, while changing the name, the neoclassical economists had also changed the nature of the discipline, if they had defined that economics is not the substantive science of economic system, but the methodological science of efficiency or of taking efficient decisions - this would be an interesting spillover of political economy, whose pillars would be the Marshalling microeconomics and game theory. In this case, economics would remain a historical science that does not start from the general equilibrium and abandons one simplifying assumption after the other until reach the real market, but would start from the a more realistic market. But no, while adopting the efficiency criterion, they wanted that economics substituted political economy in the role of the science of economic systems. The outcome could not be other than a hypothetical castle in the air, a theory based on the general equilibrium and in the rational expectations, whose main objective is to legitimize ideologically the market system and economic liberalism.

Neoclassical economics and economic liberalism came to a major crisis with the 1929 crash of the New York Stock Exchange and the 1930s' Great Depression, opening room for the Keynesian macroeconomic revolution, beginning in the 1930s and for classical developmentalism, beginning in the 1940s. With these contributions, economics returned to history and reality. And economic policymaking - the macroeconomic policies for the short run and the development policies for the long run turned into practical and strong instruments for achieving economic stability and growth. Nevertheless, in the 1980s, neoclassical economics, now endowed of a rational expectations macroeconomics, turned again mainstream. Today, we can divide economic thought into two broad economic traditions, heterodox economics and orthodox economics. Within the first tradition, besides the original classical political economy, Marx's and Keynes' economics, and development economics or 
classical developmentalism, we have, presently, post-Keynesian, Marxist, Schumpeterian, French regulationist, institutionalist economics, and new developmentalism. Within the orthodox tradition, we have neoclassical economics, Austrian economics, and new institutionalism. What distinguish the two theoretical orientations? Marc Lavoie (2014: 12) proposes five distinct presuppositions distinguishing heterodoxy from orthodoxy: realism $\mathrm{x}$ instrumentalism, satisfying $\mathrm{x}$ optimizing agent, holism $\mathrm{x}$ atomicist individualism, production and growth $\mathrm{x}$ allocation and scarcity, and regulated $\mathrm{x}$ unfettered markets. This is a good distinction, but it fails to consider the methodological distinction that I view as fundamental: while heterodox economics uses essentially a historical-deductive method, and, when uses economic syllogisms, make them conditional, orthodox economics uses basically the hypothetic-deductive method reduced to economic syllogisms; in consequence, the criterion of truth of the orthodox tradition is logical consistency, while for the heterodox tradition is consistency with reality. ${ }^{2}$

In this paper I am interested in the long-term, in economic growth with financial and economic stability, protection of the environment and reduction of inequality. I will discuss four theories, based rather in historical models than in economic syllogisms: classical developmentalism, post-keynesian economics, new institutionalism, and new developmentalism. ${ }^{3}$

\section{CLASSICAL DEVELOPMENTALISM}

Classical developmentalism was developed between the 1940s and the 1960s by economists like Rosenstein-Rodan, Arthur Lewis, Raúl Prebisch, Gunnar Myrdal, Hans Singer, Michael Kalecki, Albert Hirschman and Celso Furtado. This theoretical framework had as center of irradiation Santiago of Chile which has since 1948 been home to the Latin American Economic Commission for Latin America and Caribe of the United Nations (CEPAL in Spanish), and, for that reason, is often also called "Cepalian structuralism". Classical developmentalism is a good name because the expression "developmentalism" applies also to a real historical phenomenon - the form of economic and political organization of capitalism alternative to economic liberalism - which has characterized the industrial revolutions in each country since the first industrialization in Great Britain. Classical developmentalism and new developmentalism are theories that search to understand the real phenomenon of economic growth, which was fast and led to catching up when developmentalism was the form of organizing capitalism. As classical as well as new developmentalism are theories that adopt an historical approach, it is natural

\footnotetext{
${ }^{2}$ On the opposition between the historical and the hypothetic-deductive method, and on the distinction between historical models and economic syllogisms, see Bresser-Pereira $(2009,2017)$.

${ }^{3}$ There are other historical economic theories, particularly the Marxist political economy, the German historical school, the American institutionalism, and the Schumpeterian school.
} 
that they correspond to this form of organizing capitalism. Historically, developmentalism was the default form that capitalism assumed when each country realized its industrial revolution and turned capitalist. This is true for the central countries that originally developed, like England and France, for the latecomer central countries like Germany and the United States, and for the peripheral countries, which for some time were under the political or the practical domination of the central countries, like India, Japan and Brazil. ${ }^{4}$

As Keynesian macroeconomics, classical developmentalism was critical of neoclassical economics. ${ }^{5}$ The main contribution of classical developmentalism to economics was to affirm that economic growth is industrialization or "structural change" or, as I prefer to say today, is productive sophistication. This is explained with a series of arguments: First, industrialization was the historical condition for all countries that developed. To turn into a modern or capitalist society and increase the productivity of labor and the standards of living, traditional societies turned into nations, which formed nation-states and industrialized. ${ }^{6}$ What seems obvious - when we look to history and see that no country has developed or made its capitalist revolution without industrializing - was and continues to be rejected by a-historical neoclassical economics according to which, giving the supply factors and endowments and the law of comparative advantages, the market will decide which is the optimum course for the country. In the founding article of Latin American structuralism, Raúl Prebisch (1949: 2) claimed that "industrialization is not an end in itself, but the principal means at the disposal of those countries [at the periphery] of obtaining a share of the benefits of technical progress and of progressively raising the standard of living of the masses". ${ }^{7}$ Hans Singer (1950: 476), on the other hand, argued on the importance of the positive externalities present in industrialization: "The most important contribution of an industry is not its immediate product [...] not even its effects on other industries and immediate social benefits [...] but perhaps further its effect on the general level of education, skill, way of life, inventiveness, habits, store of technology, creation of new demand, etc."

Second, in the process of growth or of the increase productivity, the transference of labor from agriculture to manufacturing plays a key role. The increase of productivity in a country may happen either in the same industry, or in transferring

\footnotetext{
${ }^{4}$ India was a full fledge colony of the UK; Japan, a quasi-colony of the United States between 1854 and 1868 , when takes place the Meiji restoration; and Brazil was an informal colony of central countries from its formal independence (1822) until the 1930 Revolution.

${ }^{5}$ Actually, Keynes in the General Theory does not distinguish classical from neoclassical economics as both were supply-sided, having as assumption the Jean-Baptiste Say's law, which holds the supply creates its own demand.

${ }^{6}$ Dependency theory searched to disqualify the dual character of developing countries before they complete their capitalist revolution with the argument that developing societies were born capitalists. This makes little sense.

${ }^{7} \mathrm{He}$ would reaffirm this position later (1959: 251): “industrialization is an inescapable part of the process of change accompanying a gradual improvement in per capita income.”
} 
labor from the primary to the secondary sector. Assuming that labor is able to learn fast new abilities, the second method is more relevant for developing countries. In the manufacturing industry, the technological sophistication, the value added per person, and the corresponding wages (the three closely related variables) are higher than in agriculture and livestock. In rich countries, which are near the technological frontier, the last method is more relevant, and this was probably the reason why Kaldor emphasized the role of increasing returns of scale. But in developing countries the transference of labor to more sophisticated industries is the simpler and more effective method of increasing productivity. Arthur Lewis (1954), in his classical paper on growth with elastic supply of labor, recognized this fact. He argued the transference of labor from low value added per person in the traditional sector of the economy benefited the infant manufacturing industry, because the additional wage that industrialists were supposed to pay to their workers were inferior to the associated increase of the productivity. Thus, profits would be higher and the manufacturing industry would be profitable enough to accumulate capital and grow.

Third, as Raúl Prebisch (1949) and Hans Singer noted, the increase in productivity in the manufacturing industry in rich countries is not fully transmitted into the fall of prices which would benefit also the countries not producing manufactured goods, as neoclassical economics assumes, but causes the direct increase of the wages in rich countries. They argued that while the workers in these countries are organized and able to retain their productivity gains, the workers in the primary sector of developing countries are not, from what results a tendency to the deterioration of the terms of change in the developing countries. Many researches confirmed this thesis; some rejected the deterioration of the terms of change of developing countries, but none showed their improvement - and this is what neoclassical economics predicts given the fact that productivity has historically increased much faster in the manufacturing industry than in the primary sectors. All increases in productivity would result into fall of prices (which benefit all, domestically and abroad), not in increase of wages in rich countries, as actually happened.

Fourth, developing countries that are exporters of primary goods confront a "foreign constraint" originated from the two perverse income-elasticities: while the income-elasticity of imports of developing countries exporting primary goods is higher than one, the income-elasticity of imports of primary goods by rich countries is smaller than one. Economists derived from this simple fact, so clearly defined by Raúl Prebisch, the more deeply mistaken consequences (first, the "two gaps model", the gap of savings and the gap of dollars, and the conclusion that developing countries should grow with foreign indebtment, using "foreign savings"; second, the understanding of the foreign constraint as a "structural source of foreign vulnerability" leading developing countries almost inevitably to cyclical crises) although the only legitimate conclusion that we can derive from this constraint is that developing countries must industrialize to overcome this growth disadvantage. For sure, developing countries face shortages of dollars, but the way out is not get indebted 
in foreign money; for sure, they undergo cyclical financial crises, but its cause is not the foreign constraint but the mistaken belief that capital is not made at home.

Classical developmentalism didn't count with a macroeconomics. Its "structural theory of inflation" had limited scope as countries are able to overcome bottlenecks in the productive system and production turns responsive to prices. In practice, classical developmentalism adopted post-Keynesian macroeconomics, essentially the idea that fiscal policy must be countercyclical. But this does not mean to be prospending or fiscal populist as it happens to vulgar Keynesians or vulgar developmentalists, who have for all problems one simple solution, to expend more, while liberal-orthodox have also always the same policy prescription: to spend less, to engage in fiscal adjustment. Classical developmentalism defended fiscal responsibility. In Brazil, Celso Furtado's 1963 "Plano Trienal" is a good illustration of this view.

Classical developmentalism defends a moderate but strategic intervention of the state in the economy, not only because there are non-competitive sectors in the national economies even of rich countries, but also because savings are insufficient and markets in pre-industrial countries are poorly developed, poorly regulated, and not sufficiently assured by the state. The state must be a proactive actor in the economy, either as normative institution that regulates the whole society, as it is the law system and the public policies that are supposed to be consistent with the political objectives of the nation, or as an organizational institution that not only assures the law, but regulates the national money, imposes taxes, executes public policies, defines the distribution of its budget between current expenditures and investments, and makes government decision. For the neoclassical school, the only thing that the state is supposed to do is to achieve growth guaranteeing the property rights and keeping its finances balanced, while for classical developmentalism building a capable developmental state that executes the right developmental policies is essential for growth. This means that it is not enough to have a capable state, endowed with political legitimacy, sound finances and a well-structured public bureaucracy; its government must be competent in political and in technical terms. Incompetent liberal policymakers may produce bad results; the outcome of incompetent developmental policies may be worse.

The basic development strategy adopted by classical developmentalism came to be called the import substitution model. From the assumption that growth means industrialization, it involved setting high import tariffs on manufactured goods justified with the infant industry argument. Given the limited domestic markets, and the big economies of scale, classical developmentalism acknowledged that the scope of the import substitution model is small unless the country is large. Nevertheless, developmental economists did not consider the alternative of exporting manufactured goods. Instead, they proposed regional integration to increase the size of their domestic markets. As countries maintained high import tariffs on manufactured goods after one could reasonably consider the manufacturing industry "infant", the liberal-orthodoxy saw in this practice just "protectionisms". Yet, when we discuss new developmentalism, we will see that such tariffs (and, so, the import substitution model) were not protectionist, but just an intuitive way of 
neutralizing the Dutch disease on the domestic side, a way of compensating the competitive disadvantage represented by the disease, and, in this way, assuring to the national manufacturing industry equal conditions in the competition.

Classical developmentalism knew well that growth depends on the guarantee of social order to allow markets to coordinate the economy or to business entrepreneurs to invest, but its major political and institutional interest was on the national and developmental class coalition that built and turn capable the main institution in any capitalist society: the state. The capitalist revolution, which, for each people, begins with the primitive accumulation, ${ }^{8}$ and involves the formation of a nation and the industrial revolution, would not have happened if business entrepreneurs not only got assurance for their business but also counted with the support of the state, which should compensate for the several sources of disadvantages that industrialists faced in their business, as the need of time (which was in the basis of the infant industry argument) and the lack of positive externalities, which originated the first classical developmentalism model - Rosenstein-Rodan's model of the big push (1943) - the planning process of a collection of investments that created mutual externalities. ${ }^{9}$ For the formation of a capable state and an autonomous nation-state, the classical developmentalism's essential political action is to build a developmental class coalition committed to economic development and opposing to the local liberal oligarchy and the North's imperialism, which associates business entrepreneurs, the working class, and the public bureaucracy including nationalist intellectuals. I speak of a "autonomous" nation-state, knowing this makes little sense for the European countries and the former white British colonies, as well as for most Asian countries, because once the nation was formed and the nation-state was built, it is automatically an autonomous nation-state. But makes a lot of sense in Latin America, where the independence in relation to Spain and Portugal was achieved at the cost of the informal dependence to Britain, and where societies are racially mixed but the white elites identify themselves as "Europeans". Classical developmentalists were aware of such difficulty, but it was clear to them that, if the socialist revolution is not a short-term possibility, a developmental class coalition involving the industrial entrepreneurs, the public bureaucracy and the working class is the only possible alternative leading the country to growth and catching up. The assumption is that the interest of the industrialists in the domestic market and in the support of the state would be enough to motivate them to participate from the developmental coalition. This view was not formally defended by CEPAL due to its condition of an organization of the United Nations, limiting itself to refer to the

\footnotetext{
${ }^{8}$ The primitive accumulation was classically analyzed by Marx in chapter 24 of the first volume of The Capital. Profits or the surplus value was achieved in the market by capitalists, but for that it was necessary a previous capital accumulation with the use of violence or force. Thus, capitalism was preceded by a primitive accumulation, which Marx describes at length in this chapter.

9 This was the origin of François Perroux' (1955) concept of "development poles" and of the large literature on the clusters or local productive arrangements (Wilson Suzigan et al., 2004).
} 
"center-periphery" issue. The bourgeois revolution or the national-developmental political pact was for the first time defended in Brazil in the early 1950s by the nationalist intellectuals like Hélio Jaguaribe, Ignácio Rangel, Guerreiro Ramos and Álvaro Vieira Pinto, who understood economic development as a "national revolution" (the formation of an autonomous nation-state) and an industrial revolution, and view rich countries as an imperial system associated to the old Brazilian oligarchy and the liberal middle class. ${ }^{10}$

\section{THE CRISIS OF CLASSICAL DEVELOPMENTALISM}

Classical developmentalist, which was the mainstream economic theory in Latin America from the 1940s to the 1970s, came to a first crisis around 1970, when dependency theory turned the dominant interpretation of economic development in Latin America and the United States, and to a second crisis ten years later, when neoclassical economics turned again mainstream in the North. Dependency theory was a Marxist interpretation of economic development in the periphery of capitalism defined in the 1960s that rejected the possibility of a national bourgeoisie to command a developmental class coalition, confront imperialism, and achieve the national and capitalist revolution. Rich countries had counted with national bourgeoises to realize their industrial and capitalist revolution, but for dependency theory the industrial bourgeoisies in developing countries would be intrinsically dependent instead of nationalist. Thus, it was a direct critique of the central political economy proposal of classical developmentalism: the formation of a national-developmental class coalition. Dependency theory was founded by André Gunder Frank with the paper "The development of underdevelopment". He has been in Brazil at the time and wrote the paper just after the 1964 military coup in Brazil, which had counted with the support of industrial business entrepreneurs. This coup as the ones that followed in Argentina (1967) and Uruguay (1978) were understood by the left Latin American intellectuals as a confirmation of the dependency theory, of the "impossibility" of national bourgeoisies in the developing countries. But soon dependency theory was divided in two currents, the one that remained Marxist, of Gunder-Frank and Ruy Mauro Marini, and the "associated dependency" current, which was founded by Fernando Henrique Cardoso and Enzo Faletto' (1969) book, Dependence and Development in Latin America, which defended the association of the Latin American countries with the United States. In a time when Marxism had become very influential, the associated dependency interpretation had a Marxist penchant as it worked with social classes, but, effectively, it defended not the resistance to the American empire, as did classical developmentalism but the association or subordination to it. This view, which soon turned dominant in Latin

\footnotetext{
${ }^{10}$ These intellectuals published between 1952 and 1954 the five numbers of the journal, Cadernos do Nosso Tempo, and in 1955 formed the Instituto Superior de Estudos Brasileiros (ISEB).
} 
America among the Latin American intellectuals, reflected the frustration of the left in Latin America with military coups and a critique of classical developmentalism's basic political thesis: that real or fast economic development in the periphery of capitalism depends on the formation of developmental class coalition. The new interpretation saw the multinational corporation investing in the manufacturing industry of Latin American countries as proof that the center-periphery opposition was false. Not surprisingly, it was received with joy by the American academy, as Cardoso himself acknowledged (1977).

In the economic side, classical developmentalism faced a controversy with the liberal or monetarist economists - the structuralist-monetarist controversy - which didn't end with the victory of one or the other side, but hurt the developmentalists because they insisted in maintaining their interpretation of inflation based on structural bottlenecks in the agricultural sector, which even in a poor region as the Northwest of Brazil proved not be realistic. Inflation was a problem for the Latin American countries which would only find a competent interpretation with the theory of inertial inflation, but meanwhile policymakers had to confront inflation, and the structuralist view was not helpful. Albert Hirschman (1981: 183) realized that. He, who, as Mauro Boianovsky, was on the whole sympathetic to the structuralist approach to inflation, attributed the decline of the influence of structuralist economists in Latin America after the mid-1960s to their unwillingness to "forsake their doctrinal purity" and their tendency to "condemn as 'monetarist futility' the most elementary and obviously needed anti-inflationary measures". ${ }^{11}$

Dependency theory and the absence of a proposal on how to control inflation hurt classical developmentalism, but the crucial blow it suffered was the major structural change that happened around 1980 in the central countries - the change from the postwar developmental and social-democratic capitalism to a neoliberal or rentier-financier capitalism and from Keynesian to neoclassical economics as mainstream economic theory. Several factors worked for the change in the mainstream (and the hegemony of neoliberalism). First, the permanent attraction that economists feel for the mathematical reasoning that the hypothetic-deductive method adopted by neoclassical economics allows. Second, the several theoretical innovations that strengthened neoclassical economics: Solow's growth model in the 1950s, Milton Friedman, with the monetarist macroeconomics, and James Buchanan, with the public choice school, both in the 1960s, Robert Lucas, with the rational expectations macroeconomics, in the 1970s, and Paul Romer with the endogenous growth models in the 1980s. Third, the new reality and the new ideas were a reaction against the fall of the profit rate and of the growth rate in the 1980s in the United States and in Great Britain, while the inflation rate rose (stagflation), due to the increase of the power of the unions in the 1960s, and the 1973 first oil shock. Forth, the new competition originated from the first developing countries that, in the 1970s, began to export manufactured goods to rich countries benefiting

${ }^{11}$ Mauro Boianovsky (2012: 282). 
from their low wages. What happened was a change of "policy regime" or, more broadly, of the "form of economic and political organization of capitalism" from a developmental and social to a liberal form. ${ }^{12}$ This change was profound and soon encompassed all rich countries, independently if their governments were conservative or social-democratic. It turned the neoliberal ideology dominant in the Western societies and neoclassical economic dominant in the universities and in the financial markets. At the same time, trade and financial liberalization, the reduction of transports and communications costs, and the growth of multinational corporations powered globalization, which turned the material expression of neoliberalism. Thus, stronger and profiting from the policy difficulties that the social-democratic and Keynesian policies were facing, the departments of economics of the major universities became an ideological instrument of neoliberalism, i.e., of the rentier-financier class coalition as the service of small elite rentier capitalists and financiers. ${ }^{13}$ In this new world, classical developmentalism was reduced to a "protectionist advocacy of the import substitution strategy". Albert Hirschman, one of the pioneers of classical developmentalism, acknowledged its crisis in "The rise and decline of development economics" (1981).

On the other hand, in Latin America, growth had been stopped in the 1980s by a major financial crisis, the Foreign Debt Crisis, caused by the growth with foreign indebtedness policy adopted in the 1970s and its two major consequences: all countries falling into fiscal crisis and several experiencing high inflations. Given the economic stagnation and the ideological hegemony of neoliberalism, it was not difficult to the liberal orthodoxy to attribute the crisis to the import substitution strategy, i.e., to state intervention and to the protection of the manufacturing industry. This contention was essentially false. It ignored that the trade liberalization and financial liberalization reforms adopted in the end of the 1980s by Latin American countries, have had as an unforeseen consequence the dismantling of the pragmatic mechanisms that, respectively, neutralized the Dutch disease in relation to the domestic markets and kept the real interest rate low. Yet, it seemed true because the states in the region experienced a fiscal crisis, which the liberal orthodoxy explained simply with fiscal populism, but it was also resulted from the fact that, given the Foreign Debt Crisis, the state was constrained to bail out the private and state-owned corporations indebted in dollars.

Among the shortcomings of the neoliberal diagnosis of what was happening with

\footnotetext{
12 Policy regime is a concept developed by Adam Przeworski (2001), while Bresser-Pereira (2001a), writing on the "new left", remarked that in 1980 s "the political center moved to the right" and the social-democratic countries adopted policies very similar to the liberal ones, while in the post-war period the inverse had happened: the conservative political parties participated in the building of the social and developmental state.

${ }^{13}$ Yet, Keynes remained relatively present in the mainstream, because it was divided into a radically liberal current formed by the monetarist, new classical and the Austrian school economists, and the new-Keynesian school, which is basically hypothetic-deductive and neoclassical, but reserves some room for demand and acknowledge greater market failures.
} 
developing countries, one was particularly relevant. The East Asian countries had continued to grow fast throughout the 1980s, and, definitely, they were not an example of laissez-faire, but an example of the developmental form of economic organization of capitalism. They followed the Japanese model of growth, which meant a strong developmentalism. They adopted a nationalist approach and very active industrial policies. Nevertheless, the liberal orthodoxy tried to argue that the East Asian growth strategy was liberal, because it soon turned export oriented. It is true that they turned exporters of manufactured goods, but it does not mean that they turned liberal. They just realized that the import substitution strategy was not a real alternative to them, not only because their domestic markets were small, but mostly because they didn't have abundant natural resources to base their exports in commodities. Indeed, the four Asian "tigers" abandoned the import substitution strategy in the 1960s and rapidly turned exporters of manufactured goods, while they gradually opened their economies. But in the height of their growth process, they kept a firm control of the macroeconomic prices and adopted capable industrial policies.

\section{INDUSTRIAL POLICY AND HISTORICAL INCONSISTENCY ${ }^{14}$}

Classical developmentalism was in crisis from the 1970s; it had come to a theoretical standstill, as their authors were not developing new theories or new models, but two historical findings gave it a new breath. They were: in the 1980s, the key role of industrial policy in the catching up of the East Asian countries and, in the early 2000, the historical institutional inconsistency of the Washington Consensus with the growth experience of rich countries. The fact that the East Asian countries recurred widely to industrial policy became clear by the end of the 1980s, at the same time that the Washington Consensus was taking over Latin American countries. Although classical developmentalists didn't use the expression "industrial policy" but economic or indicative planning, industrial policy was the identification of growth with industrialization and with the need of a government growth strategy to industrialize the country. In the 1980s, while classical developmentalism confronted deep crisis, three books on the successful trajectories of the East Asian economies showed unambiguously that this success should be attributed to industrial policy: Chalmers Johnson's (1982) book on Japan, Alice Amsden's (1989) book on South Korea, and Robert Wade's (1990) book on Taiwan.

Johnson focuses on Japan's Ministry of International Trade and Industry (MITI), the core of the Japanese state economic bureaucracy. His argument, simply put, is that MITI's industrial policy was crucial to shift the "industrial structure", and that this shift, on its turn, "was the operative mechanism of the [Japanese] economic miracle" (1982: 31) In his words, his book "stresses the role of the developmental state in the economic miracle" (1982: 17). For the purposes of this

${ }^{14}$ This section draws on the Bresser-Pereira and Rugitsky (2017). 
paper, it is relevant to note that this description of the Japanese policies and the Japanese state in terms of a "developmental state" makes clear the contrast with the neoclassical approach. The title of his book - MITI and the Japanese Miracle: the growth of industrial policy, 1925-1975 - leaves no doubt about that. Although Johnson mentions, in several passages of the book, Japan's policies regarding foreign exchanges, the alternative between devaluation and industrial policy does not appear as such in it. The focus is on industrial policy, and exchange-rate policies play, at most, a subsidiary role in his narrative.

In Amsden (1989: 144), however, we find a more detailed examination of exchange-rate policies, in which she recognizes that changes in the exchange rate can have similar effects of subsidies, but favors direct subsidies. She discusses industrial policy as means to getting relative prices "wrong", as a fundamental strategy toward development, in contrast to the neoclassical emphasis on getting them "right". She says: "As for the foreign exchange rate, another key relative price in economic expansion, it has also been deliberately distorted by late industrializers, which need a high rate to export and a low rate to repay foreign debt and to import raw materials and producer goods that cannot yet be produced domestically". When she said that the devaluations of the won in the early 1960s were "disastrous", I believe she was wrong. According to Amsden (1989: 64-67) its "major effect [...] was worsening of the business climate by the increase in price of imported inputs, which fueled inflation" (1989: 65), Nevertheless, we read in her book that the 1961 devaluation was of $100 \%$ (the exchange rate went from 65 to 130 per dollar) and, in her Table 3.1, we learn that this was a once-and-for-all devaluation in so far that in the next 23 years the won kept its acquisitive power relatively unchanged, around 110 won per dollar (1989: 56 and 65). She maintains that the devaluations that took place in 1961 were not able to stimulate exports immediately, but she acknowledges that, in 1963 and 1964, exports started to rise sharply. Indeed, the reaction of the economy to the devaluation is not immediate, but it is powerful.

Wade's (1990) interpretation of the Taiwanese case is somewhat more nuanced. Even though he chooses to emphasize "sectorial policies", he does not disregard the role played by the exchange rate and mentions it again and again. In broad terms, his interpretation is similar to Amsden's. He argues that "the superiority of East Asian economic performance [...] [is] the result, in important degree, of a set of government economic policies. Using incentives, controls, and mechanisms to spread risk, these policies enabled the government to guide - or govern - market processes of resource allocation" (1990: 26-27). Among the policies he mentions, several could be considered forms of industrial policy - like "assisting particular industries", "building a national technology system", "prioritizing the use of scarce foreign exchange" - but also "maintaining the stability in some of the main economic parameters that affect the viability of long-term investment, especially the exchange rate, the interest rate, and the general price level" (1990: 27-28). In any case, in his analysis of Taiwan, Wade recognizes the fact that "Taiwan's real exchange rate has been [...] (prior to the mid-1980s) neither much overvalued or undervalued" and that it remained "remarkably stable" (1990: 60), he goes to great pains to document the detailed way in which 
the Taiwanese government managed its foreign trade resorting to tariffs, subsidies and numerous nontariff instruments (1990: chap. 5). It should be pointed out, nevertheless, that the exchange rate skepticism that was noticeable in the many authors discussed is less clear in Wade's work. Examining the 1980s, he argues that "the real exchange rate became increasingly undervalued [...]. This of course has given a powerful spur to exports" (1990: 148).

In the 2000s, Ha-Joon Chang (2002) and Erik Reinert (2007), both responding to the renewed interest in institutions although still faithful to new developmentalism, demonstrated with historical facts that the capitalist imperialism of rich countries in relation to the rest continued strong and represents a major obstacle to economic growth. The difference in relation to imperialism pre-Second World War is that soft power had replaced hard power; the ideological hegemony that defined the domination of the North over the South American countries now was extended to all developing countries in so far that they press them not to adopt the policies and long-term institutions that themselves embraced when they were at the same stage of growth. Reinert's How Rich Countries got Rich... and Why Poor Countries Stay Poor and Chang's Kicking Away the Ladder were pathbreaking books. They showed that an historical institutional inconsistency plagued the Washington Consensus: the very policies and institutions that the neoliberal consensus search to forbid developing countries of adopting, were the policies and institutions that they had used when they were in the same stage of growth. With these two historical discoveries, classical developmentalism experienced a revival, as the five books confirmed in historical terms the importance of industrialization and of moderate state intervention in fast growth. But they didn't represent a new theory; they didn't offer to developing countries a good explanation of their economic difficulties, nor offered a blue print to face them. The only policy recommendation was "do competent industrial policy" - competent because strategic, because conditional to the firms benefited proved ability to compete in the framework of globalization.

\section{NEOCLASSICAL OR NEW INSTITUTIONALISM}

In the late 1970s, neoclassical economics turned dominant in the universities, and, in the early 1980s, neoliberalism turned into the hegemonic ideology in rich countries' governments and in the economic elites. But the liberal orthodoxy lacked a historical theory of economic development. It only counted with abstract models, the Solow model in particular, which is eventually production functions, relating growth with capital accumulation and technical progress. Later on, neoclassical economics would work with endogenous growth models, but these were hypothetic-deductive models, mere production functions that could be subject to econometric tests, but really didn't offer an explanation why some countries grow, and others stay behind. The World Bank, on its turn, had fallen into an identity crisis when, in the early 1980s, the American government constrained it to change from a developmental multilateral bank whose policies were oriented by development 
economics to be the agency charged of making the neoliberal reforms to advance in the developing countries - to change their economic policy regimes from developmental to liberal - using the power of their loans as "conditionalities". ${ }^{15}$ The mainstream economic was back to economic syllogisms, beginning with the general equilibrium model and the law of comparative advantages, which are models that, dogmatically understood, lead policymakers rather to wrong than to good policies that really promote growth. Significantly, the same happened with Keynesians, who soon moved to economic syllogisms, beginning with the Harrod-Domar model. These models are out of the scope of this paper. ${ }^{16}$

How to give to mainstream economics also a historical perspective? Strictly, this would be impossible, given that neoclassical economics adopts radically the hypothetic-deductive method. But a compromise was eventually found. Mancur Olson made the first main attempt in this direction with The Rise and Decline of Nations (1982), but what he achieved was a radical liberal critique of state intervention, which would be determined by "distributional coalitions", by interest groups only concerned with their own benefits. He views that the ensuing protectionist policies hurt growth, but they would find little resistance since their costs are diffused throughout the whole population. Yet, his reasoning was not really historical, but essentially hypothetic-deductive. He deduced the impossibility of a beneficial collective action not so much from the observation of historical experience, but from his "logic of collective action", ${ }^{17}$ according to which the concept of public interest or common good is inexistent, and all economic agents are eventually free-riders.

It was however Douglass C. North, with his book Institutions, Institutional Change and Economic Performance (1990), complemented by a 1991 paper, who created a neoclassical historical explanation for economic growth. North was originally a Marxist, which gave him a broad historical perspective. First, he changed into a distinguished cliometrician, i.e., an economic historian that uses systematically economic theories and econometric techniques in his work; second, several years later, he turned into a theoretician as he introduced institutions in neoclassical economics. The crucial role of institutions in economic development was already in Marx, in the German Historical School (second part of the nineteenth century), and in the American Institutionalist School in the turn of the nineteenth century, but their theoretical framework was far apart neoclassical economics, in so far that institutions were always thought as endogenous to the historical process. Douglass North, without ignoring history, made institutions a product of political decisions in some crucial moments, thus, essentially exogenous. For instance, in his 1991 paper, he explains why the United States developed while the Latin American countries didn't with the economic opportunities that were open

\footnotetext{
15 Through the 1985 Baker Plan the US Treasury gave formally this role to the World Bank. On World Bank's identity crisis, see Bresser-Pereira (1995), where I discussed this major change.

${ }^{16}$ For surveys on this matter see, among others, Oreiro (2018).

${ }^{17}$ The title of his previous book: The Logic of Collective Action (1965).
} 
and the decisions that respectively England and Spain made in the colonial process, the former conducive to the respect of property rights and contracts, the later, not. This makes little sense when we study history as a dialectics between structures and institutions. Indeed, the colonization processes were very different, but they didn't result of decisions of the colonizers. Now, I just remark that North was powerful in rhetoric. He begins his book with a very simple and able definition of institutions ("they are the rules of the game"), which encompasses the law system (the state) and all the other formal and informal norms that regulate human life. He does this as if he, or the neoclassical economists, were "discovering" that institutions exist and matter. He says very little on the state or the law. He ignores that in modern, capitalist societies the main institution is the state, which is the law system and the organization that guarantees it. He is only interested in the institutional innovations (he cites three: the ones that increased the mobility of capital, that reduced the information costs, and that spread risks), which, according to him, allowed the rise market societies, i.e., capitalism. In these societies the importance of the law system, of the guarantee of property rights and contracts, turns obviously fundamental. The nation-states were born from an alliance of the monarch and his court with the emerging great bourgeoisie. North offers this idea to neoclassical economics, while makes some smart critiques of it, but essentially accepts the neoclassical way of reasoning, the role of transaction costs, the exogenous character of institutions, and adopts a radical liberalism that in the 1980s had taken over neoclassical economics. For sure, he was very well received by the economic establishment. His ideas were incorporated into the liberal orthodoxy and were followed by a large number of studies adopting the same approach, among which the one held by Acemoglu, Johnson and Robinson (2005) is the more interesting.

\section{WHY NEW DEVELOPMENTAL THEORY?}

In the 1980s, the developmental governments in Latin America failed to overcome the Foreign Debt Crisis, and, in the 1990s, they bowed to the new truth that was coming from the North. The countries engaged not only in required structural adjustment policies led by IMF, but also in neoliberal reforms coordinated by the World Bank whose validity was questionable. Not surprisingly, the reforms were adopted but the countries failed in resuming growth. Instead, we saw a deterioration: increased financial instability, low growth rates and the deepening of inequality. On the other hand, in the 1980s and again in the 2000s classical developmentalism had been unable to achieve better results. This meant that the main schools of thought at the disposal of developing countries were proving powerless in offering them an adequate guidance. This was true in relation to the two competing historical theories of economic development (classical developmentalism and neoclassical institutionalism), as well as to the two competing macroeconomic theories: post-Keynesian macroeconomics and neoclassical macroeconomics. Developing countries need specially a development macroeconomics. 
Post-Keynesian economics may also be viewed as containing a development macroeconomics, but its more celebrated model, the Thirlwall's law (1979), is nothing more than a formalization of Prebisch's two perverse elasticities. The model attracted post-Keynesians because it makes development dependent on demand essentially on exports. This assumption is only partially true, but let us accept it. Nevertheless, the formalization proved limited in explicative ability and rich in producing wrong interpretations, and mistaken policies. The formalization allowed for an infinite number of econometric studies that confirmed the obvious - that the constraint really exists, i.e., that the growth of the country is limited by exports of commodities whose demand tends to grow at a smaller pace than the increase of its demand for imports. But the only legitimate conclusion that we can derive from this is that the country must industrialize to get rid of the constraint, and that this will require an extra effort. Instead, Thirlwall and Hussain (1982: 1) searched to predict the growth rates of developing countries from the income elasticity of the imports of each country, with poor results.

New developmentalism was a response to all these problems. It is a theoretical framework that explains growth and failure to grow of developing countries, particularly the Latin American middle-income countries that suffer from the Dutch disease and from the dependency in relation to the North. A framework that was essentially macroeconomic, not because the supply side does not matter, but because, in the supply side, developing countries (except when they have predator states, which are out of the scope of this paper) are already involved in doing their best; they are truly involved in developing education and health care, in building the best institutions, in investing in infrastructure, in promoting science and technology. And because the correspondent outcomes take place only in the long-term, while the right macroeconomic policies produce almost immediate results.

It was within this context that a growing group of economists, mostly in Brazil and Argentina, started building a new development macroeconomics which, eventually, came to be called new developmentalism. In the 1980s, there was a first attempt to this direction - a first step in building a macroeconomics more adapted to developing countries with the theory of inertial inflation - a theory that is crucial to the understanding and control of high inflation, and that today is part of the mainstream. This theory had as pioneers Mario Henrique Simonsen (1970) and Felipe Pazos (1972) and achieved the first complete formulation in Bresser-Pereira and Nakano (1983), ${ }^{18}$ and Lara Resende and Arida (1984). ${ }^{19}$

After the Argentinean 2001 crisis, high inflation had been controlled in Latin

\footnotetext{
${ }^{18}$ In this 1983 paper, Bresser-Pereira and Nakano distinguished the accelerating, maintaining and sanctioning factors of inflation: supply or demand shocks and the distributive conflict responding for the accelerating factors, the formal and informal indexation of the economy for the maintaining factors, and the endogenous character of money for the sanctioning factor.

${ }^{19}$ In this 1984 paper, Lara Resende and Arida proposed the adoption of indexed money to neutralize the inertial component of inflation, instead of the table of conversion of accounts payable.
} 
America, and the problem then was to resume growth, which had been stopped twenty years before. Considering the Fernando Henrique Cardoso administration (1995-2002) in Brazil, which adopted formally the growth cum foreign savings policy, but didn't make the country resume growth (despite the foreign debt crisis and the high inertial inflation had just being solved), I realized that this policy was essentially flawed - that there was an inverse relation between the current-account deficit of a country and the exchange rate. The higher the current-account deficit, the more appreciated will be the national currency. Thus, when president Cardoso decided to grow with foreign indebtedness, he was implicitly deciding to appreciate the currency in the long-term, thus encouraging consumption and discouraging investment. In 2001, I wrote a short note on the subject, and in the next year, a full paper with Yoshiaki Nakano, "Economic growth with foreign savings?". ${ }^{20}$ In 2003 , again with Nakano, I wrote a paper on the Brazilian economy, where we made a severe critique to the high interest rates practiced by the Central Bank of Brazil, which opened room for the first serious public debate on the subject. ${ }^{21}$

Also in 2003 I used for the first time the expression "new developmentalism" (Bresser-Pereira, 2003), not because some Latin American countries were again adopting developmental policies after the obvious failure of the 1990s' neoliberal reforms that derived from the Washington Consensus. Indeed, several countries adopted economic policies based on a developmental approach, but the policies were a combination of classical developmentalism and economic populism in its two versions: fiscal and exchange rate populisms. New developmentalism was so called to underline its theoretical difference in relation to the classical developmentalism and its rejection of populist or vulgar developmentalism. In 2006 I published the paper "New developmentalism and conventional orthodoxy", which called interest, but principally on the part of political scientists who understood it as generalization of an actual form of policymaking, not as a theory. They understood the policies that Lula in Brazil and the Kirschners in Argentina were practicing as a "new developmentalism" in relation the previous "national-developmentalism", which was dominating in Latin America from the 1930s to the 1980s. This misunderstanding happened because I not clear enough on that matter. Instead of opposing new developmentalism to classical developmentalism, I compared it with "old" developmentalism - the later expression with a negative tone. This was not helpful: I put together the economists that I view as my masters - the economists with whom I learned economic development like Celso Furtado, Raúl Prebisch and Arthur Lewis - with populist practices that had plagued existing developmentalism in the 1980s and again in the 2000s. Nevertheless, the new thought continued to gain body, and, in 2010, got strengthened by the debate and approval of the Ten

\footnotetext{
${ }^{20}$ See Bresser-Pereira (2001) and Bresser-Pereira and Nakano (2002, 2003).

21 See http://bresserpereira.org.br/categoria/trabalhos-de-terceiros/debate-sobre-crescimento-comestabilidade2001/.
} 
Theses on New Developmentalism, which was discussed and signed by a group of 81 academics, mainly economists. ${ }^{22}$

\section{THE THEORETICAL INNOVATIONS}

In the following years, the construction of new-developmentalism advanced step by step, and its distinction in relation to classical developmentalism as well as to existing developmentalism turned increasingly clearer. ${ }^{23}$ It is in obvious opposition to neoclassical economics and liberal orthodoxy. As to classical developmentalism, it is rather an addition than a substitution. Its main theoretical innovations obeyed a time sequence: (a) from 2001-2006, the model rejecting growth with foreign savings, as the additional capital inflows appreciate the national currency, encourage consumption, discourage investment, and results in a high rate of substitution of foreign for domestic savings; (b) between 2007 and 2008, the model of the Dutch disease, including the definition of the current and the industrial equilibriums, its neutralization through an export-tax on the commodities that originate the disease, and the subsequent current account surplus; (c) in 2008, the model of the tendency to the cyclical and chronic overvaluation of the exchange rate, which shows that (c1) the exchange rate is not just volatile but such volatility has a sense, (c2) it happens between two financial crises, which causes a sharp depreciation and are caused mainly by the policy of growth with foreign indebtedness, (c3) in between and for several years, the exchange rate remains overvalued, (c4) in consequence, considering such exchange rate, the companies make their calculations and don't invest in manufacturing, which explains why the exchange rate is a determinant of the expected profit rate and, so, of the investment rate, thus becoming a key variable in the growth process of developing countries; (d) in the early 2000s, the idea that to grow the country must assure that the five macroeconomic prices (the interest, the exchange, the wage, the profit and the inflation rates) are kept right, but the market definitely does not assure that; (e) the realization that the right macroeconomic prices were essential for the catching up of the East Asian countries, and the endorsement of industrial policy provided that it is not understood as a substitute but as a complement to a competent macroeconomic policy; (f) in 2013, the concept of value of the exchange rate, around which the exchange rate floats according to the demand and supply of foreign money, which varies according to several facts including the variations of the terms of trade and in the capital flows; (g) in 2015,

\footnotetext{
${ }^{22}$ See http://www.scielo.br/pdf/rep/v31n5/a11v31n5.pdf.

23 The more complete exposition of the new-developmental macroeconomics is in Bresser-Pereira, Marconi and Oreiro $(2014,2016)$. I cite also the 2016 Portuguese edition of the book because new developmentalism is a work in progress and the English edition is more complete, because it was published two years later. The political economy of new developmentalism is mainly in Bresser-Pereira (2016, 2017).
} 
the model explaining the value of the foreign currency with the variations in the index of the unit labor cost of the country in relation to its main competitors; and the variations of the current equilibrium with, additionally, the variation in the terms of trade; (h) in 2016, the completion of the model of exchange rate determination, where the structural component of such determination is the value of foreign money, and where, besides other aleatory variables, the demand and supply of foreign money vary according to three habitual policies, often adopted by developing countries: the growth with foreign savings policy and the resulting capital inflows permanently in excess of outflows, the policy of using the exchange rate as an anchor against inflation, and the policy of high interest rates that attracts capital inflows and is instrumental in relation to the two previous policies.

The microeconomic innovations are more limited. New developmentalism borrowed from the classical political economy (labor value theory and the tendency to the parity of the profit rates) and, from classical developmentalism, the definition of growth as industrialization and, with less emphasis than in classical developmentalism, the defense of industrial policy. The whole new developmentalism never starts reasoning from the general equilibrium model or pure competition, as it assumes competitive or relatively free markets, but it distinguishes within modern capitalist economies a competitive and a non-competitive sector - and defends for the second, formed by the infrastructure and basic inputs companies and the great banks ("too big to fail"), economic planning and strict regulation.

New developmentalism counts also with a political economy, this expression understood as the relations between the market and the state and politics. Some of them were already part of classical developmentalism, but are important in the new-developmental framework: (a) the identification of the beginning of the economic development with the formation of the nation-state and the industrial revolution, both these two major historical changes forming the capitalist revolution in each country; (b) the distinction of economic from political populism, and the identification of economic populism not only as fiscal (the state spending more than it gets irresponsibly), but also, if not principally, exchange rate populism: the nation-state expending more than it gets and incurring in current-account deficits; (c) the affirmation of the possibility of national developmental class coalitions, although the ambiguous and contradictory character of the Latin American business entrepreneurs; (d) the definition of the developmental state as a state that intervenes moderately in the economy (practices industrial policy) and, although cooperating with the other countries, adopts economic nationalism.

To this previous knowledge on political economy we must add other newdevelopmental components, which may also be depicted as a sequence: (a) from 2006 to 2009, the definition of globalization as a competition not only among companies, but among nation-states, this inducing an imperial practice on the part of the richer and more powerful countries, which explains why developing countries must recur to economic nationalism to grow; (b) from 2010 to 2014, the more precise definition of developmental state, which is not just characterized by eco- 
nomic nationalism and a moderate intervention of the state in the economy, but also if not principally by an active macroeconomic policy that keeps the five macroeconomic prices right, particularly an exchange rate policy; (c) in 2014, the classification of developmental state in four models, according to being central or peripheral countries and their degree of autonomy: the original central model, of England and France; the latecomer central model of Germany and the United States; the independent peripheral model, of East Asia; and the national-dependent peripheral model, of Brazil and South Africa; (d) in 2015-2016, the definition of developmentalism as the form of economic and political organization of capitalism alternative to economic liberalism, and the definition of the phases of capitalism in the original countries as: mercantilism or first developmentalism, economic liberalism, the Golden Years of Capitalism or second developmentalism, and neoliberalism; (e) in the same period, the definition of developmentalism as the default form of capitalism, to the extent that not only the original central countries, but all other countries were developmental when they industrialized; (f) in 2017, the definition of contemporary capitalism as a rentier-financier capitalism, and of the phases of capitalism according to the dominant class coalition: classical or business entrepreneurs' capitalism, technobureaucratic capitalism, where technobureaucrats replaced entrepreneurs in the management of the corporations; and rentier-financier capitalism, when the heirs and speculators replaced entrepreneurs in the ownership of the corporations, while the financiers manage their wealth and play the role of their organic intellectuals.

Considering these new contributions, we can compare classical developmentalism and new developmentalism:

- classical developmentalism's main object are the pre-industrial countries, while for new developmentalism are the middle-income countries, which have already realized their industrial and capitalist revolution;

- classical developmentalism didn't count with a macroeconomics and reproduced post-Keynesian macroeconomics, ${ }^{24}$ while new developmentalism counts with its macroeconomics

- classical developmentalism was based on the thesis of the infant industry and defended an import substitution strategy, while the new developmentalism assumes that middle-income countries are able and should export manufactured goods. ${ }^{25}$

\footnotetext{
${ }^{24}$ Except in relation to the "structuralist theory of inflation", which eventually proved to have limited scope.

${ }^{25}$ Classical developmentalism's pessimism in relation to the exports of manufactured goods was a major mistake that Latin American developmental economists made. When, 1967, Brazil abandoned such pessimism and created an export subsidy that neutralized the Dutch disease on the export side (high tariffs already neutralized it on the domestic market side), Brazilian exports of manufactured goods soared. They went from $6 \%$ in 1965 to $62 \%$ of GDP in 1990.
} 
- classical developmentalism defended protection, while new developmentalism essentially demands the levelling of the playing field for the manufacturing industry - something that the market does not guarantee;

- classical developmentalism defended an overvalued currency and high import taxes, while new developmentalism defends relatively open markets and a right or competitive exchange rate which can only be achieved with a low interest rate and, in countries exporting commodities, with a variable export tax on such commodities to neutralize the Dutch disease;

- classical developmentalism defended the growth with foreign indebtedness policy, while new developmentalism rejects it and defends balanced or, when the country faces the Dutch disease, surplus current accounts; ${ }^{26}$

- classical developmentalism defended the import substitution strategy, while new developmentalism defends growth based on the export of manufactured goods, and, so, the competitive integration in international markets;

- classical developmentalism was skeptical about an exchange rate policy, preferring high tariffs, ${ }^{27}$ while new developmentalism has a theory on the determination of the exchange rate and gives to the exchange rate policy a major role in assuring equal conditions of competition to the national companies.

And we can compare the new developmental economics with post-Keynesian economics. Its macroeconomics, although based on post-Keynesian macroeconomics, has as distinctive traits:

- the use of five macroeconomic prices;

- the focus on the exchange rate and in the current account;

- a new theory of the determination of the exchange rate;

- the tendency to the cyclical and chronic overvaluation of the exchange rate, the long-term overvaluation been caused by a non-neutralized Dutch disease and the habitual policy of adopting a high long-term interest rate policy aiming to attract foreign capitals;

\footnotetext{
${ }^{26}$ In the Rosenstein-Rodan's (1943) big push model, which founded classical developmentalism, the huge and simultaneous investments that would benefit from crossed externalities, become internationally competitive and trigger economic growth were supposed to be financed by foreign money. Some developmental economists defended some conditions for the admittance of foreign investments, but none rejected foreign borrowing. Up to 1970 they viewed the shortage of foreign capitals as a major obstacle to growth. When, after the 1973 first oil shock, the major international private banks resumed finance to Latin American countries, which was unavailable since the 1929 crash and the Great Depression, developmental economists in Brazil have commemorated the "good new".

${ }^{27}$ See Bresser-Pereira and Rugitsky (2018). In this paper there are citations of Prebisch that show clearly this skepticism.
} 
- the critique of the growth with foreign indebtedness policy, which, instead of causing the increase of the rate of investment, causes a non-sustainable increase in the wages and in the revenues of rentier capitalists, and, consequently, in consumption.

\section{REFERENCES}

Acemoglu, Daron, Simon Johnson e James Robinson (2005) "Institutions as the fundamental cause of long-run growth", in Philippe Aghion, Ufuk Akcigit \& Peter Howitt, eds. Handbook of Economic Growth, Elsevier: 386-472.

Amsden, Alice H. (1989). Asia's Next Giant: South Korea and Late Industrialization. New York: Oxford University Press.

Arida, Pérsio and André L. Resende (1984 [1985]) “Inertial inflation and monetary reform”, in John Williamson, org. (1985) Inflation and Indexation: Argentina, Brazil and Israel. Washington: Institute for International Economics. Originally presented in November 1984.

Boianovsky, Mauro (2012) "Celso Furtado and the structuralist-monetarist debate on economic stabilization in Latin America”, in History of Political Economy 44(2): 277-330.

Bresser-Pereira, Luiz Carlos (1995) “Development economics and World Bank's identity crisis”, Review of International Political Economy 2(2) Spring 1995: 211-247.

Bresser-Pereira, Luiz Carlos (2001a) "The new left viewed from the south", in Anthony Giddens, ed. (2001) The Global Third Way Debate. Cambridge: Polity Press: 258-371.

Bresser-Pereira, Luiz Carlos (2001b) "A fragilidade que nasce da dependência da poupança externa" [The fragility resulting from the dependency on foreign savings], Valor 1000, September: 34-38.

Bresser-Pereira, Luiz Carlos (2003) Desenvolvimento e Crise no Brasil [Development and Crisis in Brazil], 5th edition, São Paulo: Editora 34, 2003. First edition, Rio de Janeiro: Zahar Editores, 1968.

Bresser-Pereira, Luiz Carlos (2009) "The two methods and the hard core of economics", Journal of Post Keynesian Economics 31(3) Spring: 493-522.

Bresser-Pereira, Luiz Carlos (2017) "Historical models and economic syllogisms", Journal of Economic Methodology, 25, 2018: 68-82. https://doi.org/10.1080/1350178X.2017.1368091

Bresser-Pereira, Luiz Carlos and Fernando Rugitsky (2018) "Industrial policy and exchange rate skepticism?”, Cambridge Journal of Economics, 42(3), April 2018: 617-632.

Bresser-Pereira, Luiz Carlos and Yoshiaki Nakano (1983 [1987]) "The theory of inertial or autonomous inflation", in Luiz Carlos Bresser-Pereira and Yoshiaki Nakano (1987): The Theory of Inertial Inflation, Bolder: Lynne Rienner Publisher 65-82. Original in Portuguese, 1983, "Fatores aceleradores, mantenedores e sancionadores da inflação" [Accelerating, maintaining and sanctioning factors of inflation"].

Bresser-Pereira, Luiz Carlos and Yoshiaki Nakano (2002) "Uma estratégia de desenvolvimento com estabilidade", Revista de Economia Política 21(3): 146-177.

Bresser-Pereira, Luiz Carlos and Yoshiaki Nakano (2003) "Economic growth with foreign savings?" Brazilian Journal of Political Economy 22(2) April 2003: 3-27. In English, in the website edition; in Portuguese, in the printed edition.

Cardoso, Fernando Henrique (1977[1980]) "The consumption of the dependency theory in the United States". Latin America Research Review 12(3):7-24, 1977.

Cardoso, Fernando Henrique and Enzo Faletto (1969 [1979]) Dependency and Development in Latin America. Berkeley: University of California Press, 1979. First Spanish edition, 1969.

Chang, Ha-Joon (2002) Kicking Away the Ladder, London: Anthem Press.

Evans, Peter (1992) "The state as problem and solution: Predation, embedded autonomy, and structu- 
ral change", in Stephan Haggard and Robert Kaufman, eds. The Politics of Economic Adjustment, Princeton: Princeton University Press, 1992.

Evans, Peter (1995) Embedded Autonomy, Princeton, NJ: Princeton University Press.

Frank, Andre Gunder (1966) "The development of underdevelopment”, Monthly Review 18(4): 17-31. Hirschman, Albert O. (1981) Essays in Trespassing, Cambridge: Cambridge University Press.

Johnson, Chalmers (1982) MITI and the Japanese Miracle, Stanford: Stanford University Press.

Lavoie, Marc (2014) Post-Keynesian Economics: New Foundations, London: Edward Elgar.

Lewis, Arthur W. (1954) "Economic development with unlimited supply of labor", The Manchester School 22 (2): 139-191.

Marx, Karl (1867 [1979]) Capital, Volume I. London: Penguin Books, 1979. Written between 1861 and 1866. First German Edition, 1867.

North, Douglass C. (1990) Institutions, Institutional Change and Economic Performance, Cambridge: Cambridge University Press.

North, Douglass C. (1991) “Institutions”, Journal of Economic Perspectives 5(1) Winter: 97-112.

Olson, Mancur (1965) The Logic of Collective Action, Cambridge: Harvard University Press.

Olson, Mancur (1982) The Rise and Decline of Nations. New Haven: Yale University Press.

Oreiro, José Luis (2018) Macrodinâmica Pós-Keynesiana: Crescimento e Distribuição de Renda. Rio de Janeiro: Alta Books.

Pazos, Felipe (1972) Chronic Inflation in Latin America, Nova York: Praeger Publishers.

Perroux, François (1955) «Note sur la notion de pôle de croissance”, Economie Appliquée 8, Séries D, January 1955.

Popper, Karl R. (1934 [1957]) The Logic of Scientific Discovery, London: Hutchinson. German original, 1934.

Prebisch, Raúl (1949 [1950]) The Economic Development of Latin America and its Principal Problems, New York: United Nations, Dept. of Economic Affairs. Original Spanish publication, 1949.

Prebisch, Raúl (1959) "Commercial policy in the underdeveloped countries", American Economic Review 49 (2): 251-273.

Przeworski, Adam (2001) “How many ways can be third?”, in Andrew Glyn, ed. (2001) Social Democracy in Neoliberal Times, Oxford: Oxford University Press: 312-333.

Reinert, Erik S. (2007) How Rich Countries got Rich... and Why Poor Countries Stay Poor, New York: Carroll \& Craf.

Rosenstein-Rodan, Paul (1943) "Problems of industrialization in Eastern Europe and South-Eastern Europe”, Economic Journal 53, June 1943: 202-211.

Simonsen, Mário Henrique (1970) Inflação: Gradualismo x Tratamento de Choque [Inflation: Gradualism $\mathrm{x}$ Shock Treatment], Rio de Janeiro: ANPEC.

Singer, Hans (1950) "The distribution of gains between investing and borrowing countries", American Economic Review 40, May 1950; 473-85.

Suzigan, Wilson, João Furtado, Renato Garcia e João Sampaio (2004) "Clusters or local systems of production: mapping, typology and policy suggestions", available at Econstor, https://www. econstor.eu/bitstream/10419/117079/1/ERSA2004_267.pdf. In Portuguese, in the Brazilian Journal of Political Economy: 2004, 24(4): 543-562.

Thirlwall, Anthony P. and M.N. Hussain (1982) "The balance of payments constraint, capital flows and growth rates differences between developing countries", Oxford Economic Papers 34(3) November: 498-510.

Wade, Robert (1990) Governing the Market, Princeton: Princeton University Press. 